\title{
Antifungal activity of ethanolic extract of Sphaeranthus indicus Linn. against Dermatophytes and Candida species
}

\author{
Preeja K. Sundaresan ${ }^{1 *}$, Kala P. Kesavan ${ }^{2}$
}

${ }^{1}$ Department of Pharmacology, Government Medical College, Thiruvananthapuram, Kerala, India

${ }^{2}$ Department of Pharmacology, Government Medical College, Aleppey, Kerala, India

Received: 21 September 2020

Accepted: 02 October 2020

\section{*Correspondence:}

Dr. Preeja K. Sundaresan,

Email: drpreeja79@rediffmail.com

Copyright: () the author(s), publisher and licensee Medip Academy. This is an open-access article distributed under the terms of the Creative Commons Attribution Non-Commercial License, which permits unrestricted non-commercial use, distribution, and reproduction in any medium, provided the original work is properly cited.

\begin{abstract}
Background: Sphaeranthus indicus as an entire plant or the specific parts like roots, leaves, flowers are used for treating helminthiasis, jaundice, diabetes, dyspepsia, fever, cough, hernia, gastritis, hemorrhoids, migraine, leprosy and skin diseases. The objective of this study was to evaluate the antifungal activity of ethanolic extract of the whole plant Sphaeranthus indicus Linn.

Methods: The antifungal activity of ethanolic extract of the whole plant Sphaeranthus indicus Linn was evaluated by incorporating the extract in Sabourauds dextrose agar. This property was studied in vitro using the ethanolic extract on Candida albicans, Microsporum gypseum, Trichophyton mentagrophytes and Epidermophyton floccosum by using Clotrimazole as standard drug.

Results: This study revealed that the ethanolic extract of Sphaeranthus indicus is having good antifungal activity against Dermatophytes and Candida species.

Conclusions: This study demonstrates the promising antifungal action of ethanolic extract of whole plant of Sphaeranthus indicus Linn. This feature can be exploited in the development of a newer antifungal agent from plant.

Keywords: Sphaeranthus indicus Linn, Candida albicans, Microsporum gypseum, Trichophyton mentagrophytes, Epidermophyton floccosum, antifungal action
\end{abstract}

\section{INTRODUCTION}

Infections induced by pathogenic fungi are increasingly recognized as an emerging threat to public health. ${ }^{1,2}$ The epidemiological data point out that the prevalence and incidence of fungal infection is a major public health issue. The increase in occurrence of fungal infections during recent years is due to a growth in the immune compromised population, such as organ transplant recipients and cancer and HIV patients. ${ }^{3}$ Antifungal agents are being widely used and this had resulted in the rapid development of resistance to these class of drugs. Certain commensal fungi, such as Candida species, cause infections when their human hosts become immune compromised. ${ }^{4}$ These problems are also associated with resistance to antibiotics and toxicity during prolonged treatment with several antifungal drugs. ${ }^{5}$ In several researches, extracts of various plants have been reported to exhibit antifungal properties under in vitro laboratory trials. $^{6-10}$ It has been pointed out that there is a relationship between the antifungal activity of the extracts and its bioactive compounds. ${ }^{11}$ Sphaeranthus indicus Linn is a herb commonly known as Mundi, $30 \mathrm{~cm}$ or 1 foot high with spreading branches, found all over the Indian plains, especially in hills, as weed in the ricefields. All parts of the plant are used as medicine. ${ }^{12}$ This study was done to evaluate the antifungal properties of ethanolic extract of whole plant $S$. indicus. 


\section{METHODS}

\section{Plant collection}

Sphaeranthicus indicus as a whole plant was collected locally in January from Thiruvananthapuram district, Kerala, India and it was authenticated by the pharmacognosy unit in ayurveda research institute, Poojappura, located in Thiruvananthapuram, Kerala, India. It was cleaned with distilled water. They were cut into small pieces, shade dried and ground to coarse powder form in an electric blender.

\section{Preparation of ethanolic extract}

Petroleum ether was used for pre extraction in order to defatten the material. After that soxhlet extraction was done using $90 \%$ ethanol. In the next step, the extract was distilled and then dried up in a previously weighed beaker for getting to get rid of the solvent. The filtration was done using Whatman No.1 filter paper .For further use they were stored at $4^{\circ} \mathrm{C}$. The ethanolic extract was prepared in three serial concentrations so that the effective concentration was $5 \mathrm{mg} / \mathrm{ml}, 10 \mathrm{mg} / \mathrm{ml}$ and 15 $\mathrm{mg} / \mathrm{ml}$, based on a previous study. ${ }^{13}$

\section{Antifungal strains}

Candida albicans, Microsporum gypseum, Trichophyton mentagrophytes and Epidermophyton floccosum were the antifungal strains obtained from the microbiology department of Government medical college, located in Thiruvananthapuram, Kerala, India

\section{In vitro antifungal activity}

The ethanolic extract of whole plant of $S$. indicus was incorporated in sabourauds dextrose agar (SDA) and in vitro antifungal activity was studied in $C$. albicans, $M$. gypseum, T. mentagrophytes and E. floccosum. The SDA medium was sterilised by autoclaving at $121^{\circ} \mathrm{C}$ for 15 minutes. To $5 \mathrm{ml}$ of molten medium in test tubes, the extract was added in serial concentrations so that the concentration was $5 \mathrm{mg}, 10 \mathrm{mg}$ and $15 \mathrm{mg} / \mathrm{ml}$ of the medium and allowed to slant. Clotrimazole $100 \mathrm{mcg} / \mathrm{ml}$ was used as standard and dimethyl formamide as vehicle. The media were allowed to cool to room temperature. A bit of mycelial growth was inoculated on to the medium and it was incubated at room temperature. The rate of growth of fungi was noted at the end of 4 weeks.

\section{RESULTS}

The antifungal activity was done in test tubes for greater ease of performance, reproducibility and convenience. The rate of growth of fungi could not be measured quantitatively or in terms of zone of inhibition. Hence at the end of 4 weeks as shown in the figures the experimental observation of absence of growth, or presence of growth was recorded.

As evident from (Figure 1 to 4 ) and as summarized in (Table 1), the study revealed that the ethanolic extract of $S$. indicus showed inhibition of growth of Dermatophytes and Candida strains in the three doses tested at the end of four weeks. As shown in figures, there was no growth of $C$. albicans, $M$. gypseum, $E$. floccosuma and $T$. mentagrophytes in the test tubes with serial dilutions of extract $5 \mathrm{mg} / \mathrm{ml}, 10 \mathrm{mg} / \mathrm{ml}$ and $15 \mathrm{mg} / \mathrm{ml}$ as compared to clotrimazole $100 \mathrm{mcg} / \mathrm{ml}$ which showed scanty growth. Test tubes containing dimethyl formamide (DMF), the vehicle and sabourauds dextrose agar (SDA), the culture media which acted as controls showed profound growth of the fungi at the end of 4 weeks.

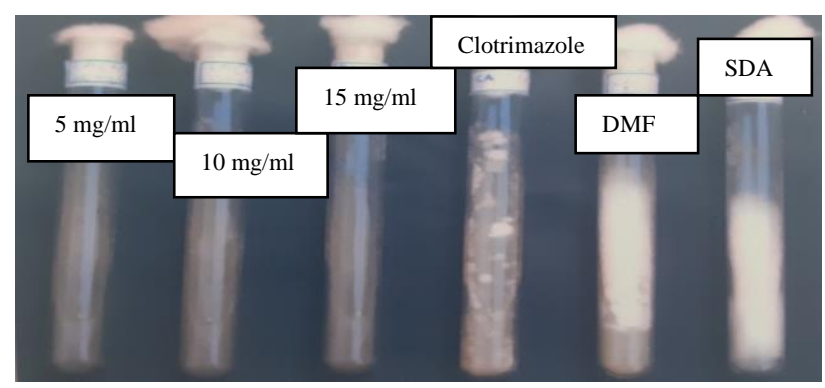

Figure 1: Effect of $S$. indicus on the growth of $C$. albicans in SDA medium compared with clotrimazole.

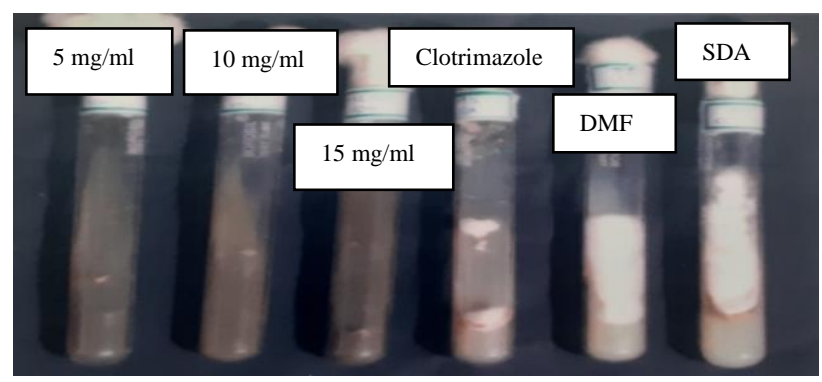

Figure 2: Effect of $S$. indicus on the growth of $M$. gypseum in SDA medium compared with clotrimazole.

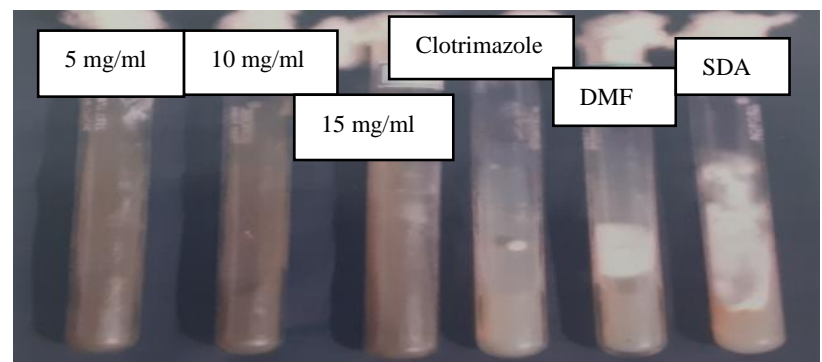

Figure 3: Effect of $S$. indicus on the growth of $E$. floccosum in SDA medium compared with clotrimazole. 
Table 1: Effect of $S$. indicus on the growth of fungus in SDA medium compared with clotrimazole.

\begin{tabular}{|llllllll} 
Fungal strain & Extract & Extract & Extract & Clotrimazole & Dimethyl \\
C. albicans & $\mathbf{5} \mathbf{m g} / \mathrm{ml}$ & $\mathbf{1 0} \mathbf{m g} / \mathbf{m l}$ & $\mathbf{1 5} \mathbf{~ m g / m l}$ & $\mathbf{1 0 0} \mathbf{m c g} / \mathrm{ml}$ & Formamide & Control \\
\hline M. gypseum & - & - & - & + & + & +++ & +++ \\
\hline E. floccosum & - & - & - & + & +++ & +++ \\
\hline T. mentagrophytes & - & - & - & + & ++ & +++ \\
\hline
\end{tabular}

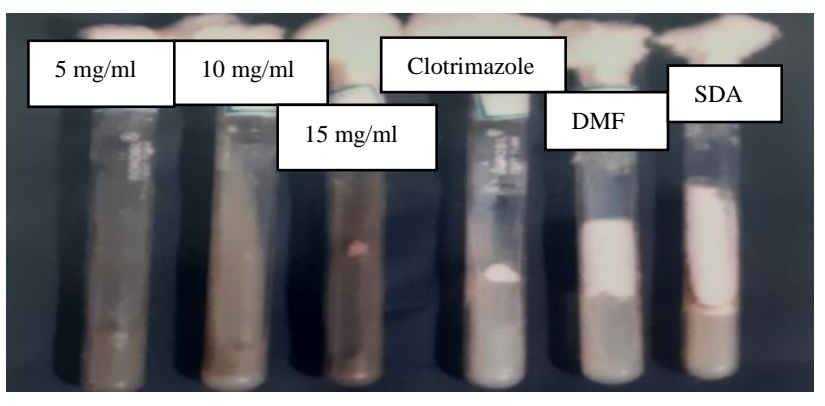

Figure 4: Effect of $S$. indicus on the growth of $T$. mentagrophytes in SDA medium compared with clotrimazole.

\section{DISCUSSION}

This study can be used to justify the use of $S$. indicus in traditional practice as a therapeutic agent as it exhibited significant antifungal properties causing inhibition of growth Candida and Dermatophytes. The antifungal properties may be due to tannins and saponins.

Hexane extract of $S$. indicus flowers possessed antifungal activity against $C$. albicans. The flower extract showed minimum inhibitory concentration (MIC) at $0.15 \mathrm{mg} / \mathrm{ml}$ and aerial parts showed MIC at $1.25 \mathrm{mg} / \mathrm{ml}$ against $C$. albicans and it is the first report on antifungal activity of $S$. indicus per the available literature. ${ }^{12}$ The antifungal activity against $T$. mentagrophytes. and E. floccosum was reported in thiophene compound isolated from Tagetes patula (Asteraceae). ${ }^{14}$ Antifungal activity was also reported for the ethanol extract of underground parts of Leuzea carthamoides (Asteraceae) and Centaurea hermanni (Asteraceae) against C. albicans, A. fumigatus. ${ }^{15,16}$

Juice of Garcinia mangostana contains polyphenolic compound such as flavonoid and tannin. ${ }^{17}$ It also contains $\alpha$-mangostin compounds which are proven to have potential antifungal and antibacterial activity. ${ }^{18}$ Xanthone is the major compound of G. mangostana showed highantifungal activity (against $C$. albicans and Aspergillus niger). ${ }^{19}$ In a study evaluating the anticandidal activity of pomegranate peel extracts (PPE) and application of PPE aerosol as sanitizer agent against exhibited potent anticandidal activity against $C$. albicans strains compared with standard fungicides in both susceptibility techniques used. Methanol, ethanol and water extracts were the most effective for inhibiting C. albicans growth. PPE aerosol was an efficient method for complete sanitizing of semiclosed places against $C$. albicans growth. ${ }^{20}$

\section{Limitations}

Since the study was a quantitative one and done in test tube we could not measure the zone of inhibition and hence statistical evaluation could not done. More studies need to be conducted with disc diffusion method for the tested fungal species. We did not identify the active principle. However, to obtain a novel drug chemical nature of active principle should be isolated and standardized and tested in more species of fungi.

\section{CONCLUSION}

S. indicus whole plant ethanolic extract can be used as a potential antifungal agent against Dermatophytes and Candida species. As whole plant was used, various phytochemicals could probably have contributed to antifungal activity. There is paucity of scientific data about the mechanism of action of the extracts. So further studies should be done to find out the molecular actions as well as pre clinical studies done to establish antifungal action of $S$. indicus extracts. The results of this study give a scientific proof for the traditional use of $S$. indicus against common fungal pathogens. This study reveals that the ethanolic extracts can be used as a potential lead to discover newer antifungal agents.

\section{ACKNOWLEDGEMENTS}

I am greatly indebted and deeply thankful to Dr. Dhanya SP, Associate professor, Department of Pharmacology, Government medical college, Kottayam for guiding me with synergy methodology, results interpretations and for comments that greatly improved the manuscript.

Funding: No funding sources Conflict of interest: None declared

Ethical approval: The study was approved by the Institutional Ethics Committee

\section{REFERENCES}

1. Wu TC. On the development of antifungal agents: perspective of the US Food and Drug Administration. Clin Infect Dis. 1994;19:S54-8.

2. Walsh TJ, Gonzalez C, Lyman CA, Chanock SJ, Pizzo PA. Invasive fungal infections in children: 
recent advances in diagnosis and treatment. Adv Pediatr Infect Dis. 1996;11:187-290.

3. Portillo A, Vila R, Freixa B, Ferro E, Parello T, Casanova J, et al. Phenylethanoid glycosides from Cistanches salsa inhibit apoptosis induced by 1methyl-4-phenylpyridinium ion in neurons. J Ethnopharmacol. 2005;97:49.

4. Cannon RD, Holmes AR, Mason AB, Monk BC. Oral candida: clearance, colonization or candidiasis? J Dent Res. 1995;74:1152-61.

5. Giordani R, Trebaux J, Masi M, Regli P. Enhanced antifungal activity of ketoconazole by Euphorbia characias latex against Candida albicans. J Ethnopharmacol. 2001;78:1-5.

6. Terzi V, Morcia C, Faccioli P, Valè G, Tacconi G, Malnati M. In vitro antifungal activity of the tea tree (Melaleuca alternifolia) essential oil and its major components against plant pathogens, Letters in Applied Microbiology. 2007;44(6)613-8.

7. Parekh J, Karathia N, Chanda S. Evaluation of antibacterial activity and phytochemical analysis of Bauhinia variegata L. bark. Afr J Biomed Res. 2006;9(1):53-6.

8. Aliero AA, Afolayan AJ. Antimicrobial activity of Solanum tomentosum. African J of Biomed Rese. 2006;5(4):369-72.

9. Buwa LV, Staden JV. Antibacterial and antifungal activity of traditional medicinal plants used against venereal diseases in South Africa. J Ethnopharmacol. 2006;103(1):139-42.

10. Ergene A, Guler P, Tan S, Mirici S, Hamzaoglu E, Duran A. Antibacterial and antifungal activity of Heracleum sphondylium subsp. Artvinense. African J Biomed Res 2006;5(11):1087-9.

11. Abdelghani SB, Weaver L, Zidan ZH, Hussein MA, Keevil CW, Brown RCD. Microware-assisted synthesis and antimicrobial activities of flavonoid derivatives. Bioorganic \& Medicinal Chemistry Letters. 2008;18:518-22.

12. Duraipandiyan V, Kannan $\mathrm{P}$, Ignacimuthu $\mathrm{S}$. Antimicrobial activity of Sphaeranthus indicus. Ethnobotanical Leaflets. 2009;13:320-5.
13. Farahmand S, Rasooli A, Saffarpour M. Antifungal activities of methanolic extract of plants. Electronic Journal of Biology. 2016;S1:42-4.

14. Romagnoli C, Mares D, Sacchetti G, Bruni A. The photodynamic effect of 5-(4-hydroxy-1-butinyl)-2,2'bithienyl on dermatophytes. Mycol Res. 1998;102: 1519-24.

15. Chobot V, Buchta V, Jahodarova H, Pour M, Opletal L, Jahodar L, Harant P. Antifungal activity of a thiophene polyine from Leuzea carthamoides. Fitoterapi.a 2003;74:288-90.

16. Sur-Altiner D, Gurkan E, Sarioglu I, Tuzlaci E, Ang O. The antibacterial and antifungal effects of Centaurea hermannii. Fitoterapia. 1997;68:374.

17. Izzati NN, Diniatik D, Rahayu WS. Aktivitas antioksidan ekstrak perasan daun manggis ( $G$. mangostana.) berdasarkan metode DPPH (2.2 Diphenyl-1-phycryl hydrazil). Pharmacy. 2012;9: 111-21.

18. Ibrahim MY, Hashim NM, Mariod AA, Mohan S, Abdulla MA, Abdelwahab SI, et al. $\alpha$-Mangostin from G. mangostana Inn: An updated review of its pharmacological properties. Arab J Chem. 2016;9: 317-29.

19. Narasimhan S, Maheshwaran S, Abu-yousef IA, Majdalawieh AF, Rethavathi J, Das PE, et al. Antibacterial and anti-fungal activity of xanthones obtained via semi-synthetic modification of $\alpha$ mangostin from Garcinia mangostana. Molecules. 2017;22:E275.

20. Tayel AA, El-Tras WF. Anticandidal activity of pomegranate peel extract aerosol as an applicable sanitizing method. Mycoses. 2010;53(2):117-22.

Cite this article as: Sundaresan PK, Kesavan KP. Antifungal activity of ethanolic extract of Sphaeranthus indicus Linn. against Dermatophytes and Candida species. Int J Basic Clin Pharmacol 2020;9:1646-9. 